\title{
ÁTMENET A SZOCIALIZMUS REJTETT HAJLÉKTALAN VILÁGÁBÓL A KVÁZI JÓLÉTI SZOCIÁLIS VÉDŐHÁLÓBA
}

\author{
(Transition from the Hidden Homeless World of Socialism \\ to the Quasi-welfare Social Safety Net)
}

\author{
NAGY TERÉZIA
}

\begin{abstract}
Kulcsszavak:
hajléktalanok posztszocializmus szegénység kapcsolatok köztér-használat

Jelen tanulmányban a magyar hajléktalanság problémáit, történeti gyökereit, esélyeit vizsgáljuk. A szegénység (ezen belül a hajléktalanok) posztszocialista sajátságait, kapcsolatait terepmunka-tapasztalatok által interpretáljuk, melyet kiegészítünk azon szempontokkal, amelyek a hajléktalanok térbeli megjelenésére reflektálnak. Azt is vizsgálat tárgyává tettük, hogy a hajléktalanok új megjelenése milyen kihivásokat jelentett a szakpolitikák számára.
\end{abstract}

\section{Bevezetö}

A második világháború utáni időszakban csak a kilencvenes években jelentek meg a hajléktalanok Magyarországon, mint amolyan társadalmi probléma, s egyáltalán, mint jelenség. Írásunkban be kívánjuk mutatni, hogyan tünnek fel a társadalom mezejében, milyen okai vannak, hogy ilyen későn manifesztálódik ez a probléma, s hogy a hajléktalanok mi módon voltak jelen korábban, még ha látens módon is. Emellett azt is szeretnénk interpretálni, hogy miben és mennyire hasonlít a magyar jelenségegyüttes az amerikai és más országok hajléktalan-problémáira. Ezen túlmenően azt is vizsgálat tárgyává tettük, hogy eme új jelenség milyen új kihívásokat jelent a szakpolitika számára, s a helyi és országos kormányzati szervek, valamint a civilek milyen lépéseket tettek (vagy nem tettek) a hajléktalanság felszámolására avagy újbóli, de új úton való elrejtésére. Az, hogy elrejtéséról beszélhetünk, azt is jelenti, hogy a hajléktalanság megjelenését tértermelési folyamatként is kellett értelmezni.

Nem tekinthetünk el attól sem, hogy a szegénység-politika szempontjából megvilágítsuk, hogy a magyar helyzet, politika és strukturális változások miben különböznek a más történelmi-gazdasági fejlödési stációkat megjárt USA-tól, s ez hogyan befolyásolja a hajléktalanná válók sorsát. Emiatt ki kell térnünk a szocializmus és az átmenet évei szegénységének attribútumaira, amely sajátságok strukturálisan, némelykor individuálisan is gyökeret jelentenek a hajléktalansághoz vezetỏ utakban. Mégha a rendszerváltás után el is telt mintegy 18 év, az akkori időszak sajátos lehetőségei, korlátai és a változások rányomták a bélyegüket a jelen szegénységére, hajléktalanságára. Azonban azt is látni fogjuk, hogy a világ számos pontján alkal- 
Nagy Terézia: Átmenet a szocializmus rejtett hajléktalan világából a kvázi jóléti szociális védőhálóba. - Tér és Társadalom, 23. 2009. 3. 79-96. p.

mazott „,best practices” alkalmazásával milyen eltérő jelenségekkel szembesültek és így milyen eredményekkel jártak.

Kutatásunk a hajléktalanok életút-interpretációin keresztül mutatja be az utat, amely a hajléktalansághoz vezet. Eredeti célunk az volt, hogy a kirekesztettségükkel párhuzamosan vizsgáljuk azt, ahogy a hajléktalan-kultúrába bezáródnak. A terepmunka 2002-2004 között intenzíven, majd idöszakosan folyt Szeged területén, melynek során megfigyelöként vettem részt a hajléktalan csoportok mindennapjaiban és interjúkat készítettem. Az élettörténetek által konstruált képet kiegészítettük a magyar szegénység szociológiai irodalmával.

\section{A tabu: szegénység a szocializmusban}

A szocializmusban nem létezett a hajléktalanság, a szegénység tabu téma volt, melyröl csak a puha-kommunizmus éveiben kezdtek beszélni a társadalomtudósok (ld. Kemény 1979; Gönczöl 1982; 1991; Ferge 1982; Bokor 1987). Más szocialista országok szegénységére vonatkozó írásokkal összevetve is viszonylag kevéssé vizsgált volt e jelenség (ld. Eberstadt 1988; Höjdestrand 2003).

A rendszerváltás után, látjuk majd, nyilvánvalóvá válik a szegénység léte, megjelenik a munkanélküliség, a hajléktalanság, a tartós depriváltság sokféle formája. Azonban a kutatók a gazdaság- és a társadalomváltozás más szegmenseire irányították figyelmüket. Így a posztkommunista magyar szegénység antropológiai nézópontból egy kevéssé vizsgált terület. Egyes részei, mint a rurális szegénység, a romák vagy a lakótelepi fiatalok megjelennek a leírásokban, de a szegénység széles spektruma maradt feltérképezetlen. A posztszocialista átalakulás, az új szegénység és tulajdonképpen az átmenet ,győztesei" sem kerültek a hazai antropológia fókuszába. A (fỏképp néprajzi) kutatások nem hatoltak be a város területére. A városi ifjúsági szubkultúrák kutatása, majd pedig egy-egy történeti-antropológiai tanulmány jelentette az antropológiai megközelítést (mindehhez ld. Köbányai 1980; 1982; Simonyi 1995; Kürti 2002) A külföldi antropológusok többnyire a posztszocializmus gazdasági vonatkozásaival, a piaci átalakulással, a termelószövetkezetek megszünésével foglalkoztak. A kutatásaikkal szemben a hazai antropológusok szempontja az, amely a mélyebb megértést, a folyamatok mélyének megértését garantálják. Tanulmányunkban ezt a nézőpontot kívánjuk érvényesíteni, mellyel célunk az, hogy a magyarországi történeti-gazdasági változások fényében mutassuk be a hajléktalanság új jelenségét. Hiszen ezek azok a változások, amelyek más sajátságokkal töltik fel a hajléktalan kultúrát, másokkal, mint ott, ahol lassan fejlődött ki a szegénységnek ez az aspektusa (ld. Costa Nunez 1996; Hazra 2005). 
Nagy Terézia: Átmenet a szocializmus rejtett hajléktalan világából a kvázi jóléti szociális védőhálóba. - Tér és Társadalom, 23. 2009. 3. 79-96. p.

\section{A szegénység a szocializmus végóráiban}

A szegénység az a tény, amelyről, ha tudtak is, nem beszéltek (Szalai 1997). A szegénység fogalma alapvetően az átlagos jövedelemtől való eltérést és életmódot jelentette. Többnyire nem jelentette a látható nyomort, habár a települések perifériáin, a pusztuló tanyákon ez is megnyilvánult. Jelentette viszont a hatalomtól, az érdekérvényesítés képességétől való megfosztottságot, az átlagos életszínvonaltól és lakásszínvonaltól való eltérést, és jelentett egyfajta életmódbeli sajátságot is (Bokor 1987). Az alkoholfogyasztás, a jövedelem rossz beosztása, a rossz egészségi állapot, a gyermekek és felnőttek higiéniájának elhanyagoltsága, az alacsony képzettség - ezek mind megnyilvánultak a szegénysorúak körében. Az iskolázottságnak alacsony presztízst tulajdonítottak, sokkal fontosabb volt az önálló család megalapítása és a munkába állás. $\mathrm{Az}$ alkoholfogyasztás fontosabb volt az életszínvonal megtartásánál, s olyan problémákhoz is vezetett, mint a házastárs és gyermekek bántalmazása vagy a bủnözés.

Marginális területeken a lakóépületek lelakása is megfigyelhetỏ volt, amely részben következménye volt annak, hogy a lakások olyan családok birtokába kerültek, akik nem voltak képesek fenntartani, a felújításról és állagmegóvásról nem gondoskodtak.

Mindez azonban nem volt beszédtéma, hiszen ők nagy többségükben mégis dolgoztak, volt lakóhelyük, viszonylag rendezett életmódot folytattak. Az alkoholfogyasztás általánosan elfogadott volt, az erőszakról és a hitelek halmozódásáról nem beszéltek. A szegénység szégyenletes és láthatatlan volt (Bokor 1987). Volt azonban néhány jelenség, amely a depriváltságot megmutatta, néha kicsit színpadiasan is: a csövesek, csavargók és közveszélyes munkakerülők világa. Mások, úgy tünt, hogy elrejtették a megfosztottság, kirekesztettség és veszélyeztetettség jelenségeit (mint pl. teljes foglalkoztatottság és munkásszállók).

\section{Csövesek, csavargók és közveszélyes munkakerülök}

A szocializmus időszakában sem volt teljesen ismeretlen a hajléktalanság jelensége - csak még nem nevezték, nevezhették így. Voltak azonban csavargók, csövesek és közveszélyes munkakerülők. Csavargó az, aki az utcán, a városok között és vidéken kóborol, alkalmi munkákat is elvállal, de alapvetően a könnyü pénzkeresési módokat részesíti előnyben. Egy részük - fóleg fiatalok - sajátos ideológiával felvértezve költöztek el otthonról, mondván, hogy a szabadság és kötetlenség, a különböző autoritások elöl menekülnek, így a szülő, a munkahely, az iskola elől. A szabadság „édes íze” fôleg nyáron volt vonzó, akkor többen, időszakosan is kiköltöztek a szabad ég alá. Többségük mára már családdal rendelkező munkavállalókká vált. A csövesek előbbiekhez hasonlóan „életmódot váltottak”, ők azonban elsősorban a nagyvárosok terein és koncerteken tüntek fel. Elnevezésük is sokak szerint innen ered - az épülö lakótelepek házaihoz használt csövekben húzták meg magukat (Utasi 1987).

Mások differenciált okoknál fogva kerültek közéjük: bủntény miatt, iskolai kudarc miatt, gyermektartási kötelezettség elől menekülve, vagy csak „könnyen élve”. 
Nagy Terézia: Átmenet a szocializmus rejtett hajléktalan világából a kvázi jóléti szociális védőhálóba. - Tér és Társadalom, 23. 2009. 3. 79-96. p.

Megint mások hasonló sorsra jutottak ügyetlenségük, fogyatékosságuk okán, de ők a csỏvesek világába sem integrálódhattak.

A fiatalok alkalmi munkából, illegális jövedelmekből tartották fenn magukat loptak, lejmoltak, receptet hamisítottak, prostituálódtak és prostituáltakat dolgoztattak. Az idősebbek hulladékok gyüjtögetéséből is éltek, gagyi arannyal kereskedtek. Mindez tehát nem fért a legális jövedelemkeresési módokba, a hivatalos munka nélküliséget a társadalom és a politika a társadalmat fenyegető veszélyforrásnak tekintette. Azokat, akik az iskolából nem a munkahelyre, vagy az egyik munkahelyet elhagyva nem egy másik munkahelyre mentek át, hanem azt megszakitva csavargó életet éltek vagy csak munka nélkül éltek, élósdinek, közveszélyes munkakerülónek tekintették (Ferge 1982). E státusz nemcsak a társadalom rosszallását váltotta ki, hanem „karhatalmilag” is közbeléptek, s munkába állították (interjú M. R. volt közveszélyes munkakerülővel 1998/2).

Az utcán azonban szinte egyikük sem aludt, legfeljebb parkok padjain nyári napokon. Egyébként nyaralókban, szanálásra itélt házakban, engedély nélkül épített viskókban, ágybérleten. Egy részük a téli időszakot munkásszállón, kórházban, elmegyógyintézetben kívánta eltölteni, míg néhányuk a börtönt is ilyen idényszállásnak tekintette (Köbányai 1980; Utasi 1987; interjú Malaccal 2002/5).

\section{A munkahelyek és a munkásszállók, amelyek elrejtenek}

A munkahely és a munkásszálló az, amely elrejtette a munkanélküliséget és a hajléktalanságot - mondják (ld. Spéder 2002, 45), s igazolva is látják a véleményüket, hiszen elöbbiek megszünésével fel is tünt a munkanélküliség és hajléktalanság „intézménye". A probléma kettéválasztásával világíthatjuk meg e nézet tarthatatlanságát.

A munkahelyek a teljes foglalkoztatottság jegyében valóban túlfoglalkoztattak, de ez sem a munkavállalók, sem pedig a munkaadók számára nem volt nyilvánvaló, hiszen akik a gyár, az intézet területén belül voltak, munkával jól ellátottak voltak. Senki nem volt dologtalan. Dolgoznak, csak a munkájuk felesleges - írja Ferge (1982). Felesleges, mert amikor dolgoznak felesleget termelnek, amely nem kerül felhasználásra, raktári tétellé lesz.

A munkásszálló ideiglenes elhelyezést biztosít a munkásnak. Azonban akik ott éltek, hamar megtapasztalták, hogy ez az ideiglenesség hosszú időre szól (Veres 1979; Láng-Nyilas 1987), ahogy azt Mátyus (1978) írja, ez a jövőt nem biztosító jelen. Az ott lakók rengeteget dolgoztak, hogy az idöt eltöltsék, s több pénzük legyen, a szórakozást is túlzásba vitték, a kapcsolatokat kritika nélkül elfogadták, miközben a bent élök között kulturális szakadékok tátongtak (Mátyus 1978). A bent élők többsége egy tradicionális, paraszti életformából érkezett a nagyvárosba, ahol nem óvta őket a közösség (Diósi 1978). Akik vidékről érkeztek, többnyire nem tartották az otthoniakkal a kapcsolatot. Az elidegenedés, a kilátástalanság jellemezte a munkásszállók világát. Azonban amikor megszủntek, nagy ür támadt mögöttük. Azoknak, akik állami gondoskodásból kerültek a szállóra, vagy az otthoni kapcsolataikat hanyagolták el, nem volt hova menniük (Láng-Nyilas 1987). Ha volt munká- 
Nagy Terézia: Átmenet a szocializmus rejtett hajléktalan világából a kvázi jóléti szociális védőhálóba. - Tér és Társadalom, 23. 2009. 3. 79-96. p.

juk, vagy megtakarított pénzük, akkor albérletbe költöztek, ha nem volt, vagy néhány év múlva elveszítették, s nem volt más kapaszkodójuk, az utcára kerültek. Az azonban, hogy a munkásszálló a hajléktalanságot rejtette volna el, nem teljesen igaz. A munkahely irányába való migrációt segíto jelenség volt, többségében olyanok számára, akiknek volt otthonuk. Az időközben kialakuló családi és kulturális konfliktusok viszont ténylegesen megteremthették a lehetőségét annak, hogy már nem volt onnan hova hazamenni.

\section{A posztkommunizmus kihívásai}

A rendszerváltás után a szocializmus kvázi-biztonsága megszủnt, a posztkommunista évek kezdetén a szegényebbek jelentős és nehéz változásokkal és kudarcokkal kellett, hogy szembenézzenek. Mindeközben azokat a fogalmakat is elveszítették, amelyek a rendszerváltást megelőzően olyan tiszták voltak: az öndefiníciókat, az ideológiát, a képességeikbe vetett hitet (Šiklova 1996; Laki 2003).

A piacgazdaságba való átmenet során a teljes foglalkoztatottság megszünt, versenyképes munkavállalókra, szakképzettekre volt szükség. De fizikai dolgozókra semmiképp sem abban a mennyiségben, mint korábban: a gyárak, üzemek nagy része megszünt, a bányákat bezárták, a feldolgozóipar fuldoklott. A munkavállalók a biztos munkahely helyett új és újabb munkahelyekre kerültek, s közben talán munkanélküliekké is lettek. A munkanélküliség réme hirtelen tört be a köztudatba (Laki 2003).

A lakásrendszer is megváltozott. Nem épültek már tanácsi lakások, s a lakásárak az egekbe szöktek. A lakáshitelek visszafizetése reménytelenné vált sokak számára, $\mathrm{s}$ a fiatalok lakáshoz való jutása még inkább reménytelenné. A munkásszállók a munkahelyekkel egyszerre zárták be kapuikat. Azok, akik munkát nem találtak, $\mathrm{s}$ ha haza sem mehettek, az albérletek bizonytalanságában találták magukat.

A második gazdaság vállalkozói a piaci viszonyokhoz alkalmazkodva vállalkozásokat nyitottak, melyek közül soknak a léte szintén bizonytalan volt. Viszont feketén dolgoztattak. Akik viszont feketén dolgoztak, bizonytalan jövőt láthattak maguk elött (Simonyi 1995; Jancius 2002; Borboly et al. 2003).

A lakosság nagy hányada fogyasztott alkoholt, nem ritkán a munkahelyén. A rendszerváltást követỏen ez megengedhetetlen volt. Megváltozott a munkamorál, a munkahelyi rend, s aki nem alkalmazkodott hozzá, hamar „visszakapta a munkakönyvét”.

A szocializmusban a jövedelmek ugyan nem voltak magasak, de meg lehetett élni belölük. Az alacsonyabb társadalmi státuszúak jövedelme is elégséges volt, hiszen az állami támogatásban részesüló (dotált) fogyasztási cikkek, tartós fogyasztási cikkek számukra is elérhetőek voltak. Sajátságos, hogy a jövedelmek nem voltak adóval terheltek, a szakszervezeti hozzájárulások alacsonyak voltak. Mindez a rendszerváltás után megváltozott: a dotációk lekerültek a termékekről, a szakszervezeti juttatások megszüntek. A jövedelmek ugyanakkor alacsonyak maradtak (Laki 2003), s ráadásul bizonytalanok voltak. 
Nagy Terézia: Átmenet a szocializmus rejtett hajléktalan világából a kvázi jóléti szociális védőhálóba. - Tér és Társadalom, 23. 2009. 3. 79-96. p.

$84 \quad$ Nagy Terézia

TÉT XXIII. évf. 2009

Korábban úgy tünt, hogy a „mellékes” ad egy biztos jövedelem-kiegészítést. A rendszerváltás után azonban sokaknak ez maradt csak, mivel a vállalatok megszüntek. A második gazdaságban megszerzett tapasztalataikat kellett átültetni a piacgazdaság valós keretei közé.

1995-ig kiderült, hogy mely vállalkozók azok, akik a piacgazdaság körülményeinek megfelelnek a korábbi, második gazdaságban megszerzett rutinjaikkal s alkalmazkodásukkal, s melyek azok, akik nem.

\section{Posztszocializmus és neoliberalizmus Magyarországon- a hajléktalanság nézöpontjából}

A rendszerváltás után a gazdasági problémák megoldására helyeződik a hangsúly, miközben a szociális szempontok háttérbe szorulnak. Az egyén felelőssége megnövekszik, az állam gondoskodó szerepe háttérbe húzódik - melynek egyrészt gazdasági okai, másrészt olyan okai vannak, mint a nyugat-európai modellek átvétele, vagy ahogy Tóth $(1994,313)$ fogalmaz: „részben tudatos reformpolitikák, részben pedig a gazdasági átmenet következményeként a [jóléti] intézményi szerkezet változik". A szocializmus gondoskodása után a jóléti állam lépcsőfoka nélkül a magyar társadalomnak hirtelen kellett szembesülnie az önállósággal és a saját felelősséggel. A jóléti kiadások csökkennek, a segélyek hozzáférhetősége nehezebb, a polgár adminisztrációs terhei, valamint az adó- és járulékterhek nönek. Fokozatosan lekerülnek a dotációk az energiahordozókról, s ennek következtében a lakosság terhei, a fogyasztási cikkek árai is növekednek. A korábban ÁFA-mentes alapvető élelmiszereket ÁFA-val terhelik.

Már a kilencvenes évek elején látható volt, hogy a jóléti kiadások ugyan a GDPhez mérten a nyolcvanas évektöl növekedö trendet mutattak, $\mathrm{s}$ akkoriban magasabb volt a GDP-hez mért arányuk, mint más fejlett országokban (vö. Tóth 1994), de reálértéken csökkentek. A jóléti kiadások az utóbbi években - pl. mint az egészségügyi és közoktatási intézmények támogatása - tovább csökkentek, ahogy a fogyasztási ártámogatások, a családi közvetlen támogatások és az adókban érvényesíthető támogatások is. A korábban ingyenes, $\mathrm{s}$ bárki által hozzáférhető egészségügyi ellátás a biztosítottak körére korlátozódik.

A szegénység-diskurzusok - ahogy máshol is - akörül folynak, hogy érdem szerint vagy tehetetlenül válik valaki szegénnyé. $\mathrm{S}$ ha egyik vagy másik mellett érvelnek, milyen támogatást érdemelnek a rászorulók. E diskurzust elmélyíti, hogy egyre bizonyosabb, hogy egyes csoportok a szociális ellátásokból élnek, s nem is kívánnak dolgozni.

A hajléktalanellátás a kilencvenes évek elejétől kezdve növekszik, igaz, korábban nem volt, de a növekedés mindmáig elmarad az igényektől. Ráadásul egyre többen veszélyeztetettek, és a hajléktalanok száma a kezdeti ugrásszerü növekedés után - ha lassabb ütemben is, de - növekszik. Mivel a szociális lakásépítés alacsony, öneró híján a szociális lakásvásárlási támogatást nem tudják kihasználni, a kevés albérleti támogatás és a hajléktalanszállók maradnak menedékül azoknak, akik nem egyénileg 
Nagy Terézia: Átmenet a szocializmus rejtett hajléktalan világából a kvázi jóléti szociális védőhálóba. - Tér és Társadalom, 23. 2009. 3. 79-96. p.

oldják meg a szállásukat ${ }^{1}$. A munkahelyteremtö támogatás, ha célzott is, nem sikeres, mert nincs lehetőség arra, hogy az egyes egyén folytassa. A rehabilitáció keveseket ér el, s látjuk majd, hogy a hajléktalanok kapcsolathálói hogyan hatnak a rehabilitáció ellenében. A befogadófalu program ${ }^{2}$ kevés hajléktalan családot érint, a szociális gazdaságok kiépülése jelenleg még csak kezdeti szakaszban van. A hajléktalanok ellátása azonban elsősorban a városok és a föváros, valamint az ott müködő civilek terhei. A szálláshelyek, nappali ellátók, utcai szociális munkát végzök száma lassan, de növekszik.

A problémák megoldására korábban hajléktalanügyi miniszteri biztost neveztek ki. A kormányzati irányelvekben a hozzáférhetőség, esélyegyenlőség elve ugyan szerepel, a kisközösségi kooperációra is hangsúly kerül, de ugyanakkor a neoliberális elveknek megfelelően az egyén felelősségét is hangsúlyozzák. Az állami szabályozás megengedi, hogy a helyi szabályozásokban megtiltsanak egyes tevékenységeket - a köztéren való kéregetéstől a dohányzásig bezárólag több minden megfogalmazásra is kerül, s a hajléktalanoknak nincs olyan érdekérvényesítő képessége, mint más csoportoknak, hogy ezeket visszavonassák. Azonban a helyi erőknek csak éppen az nem sikerülhet, amely a legegyszerübb megoldása a szegénység elrejtésére a turisták elől: fallal, ideiglenes fallal eltakarni a szegénynegyedet. A gentrifikáció (Timár-Nagy 2007) azonban megjelenik több városban. A lakhatási nehézségekkel küzdők, azok, akiknek likviditási problémáik vannak, kénytelenek elhagyni a belvárosi lakásaikat, s kintebb lakást/albérletet találni. A belvárosi tömbfelújítások gyakran végződnek kvázi-lakosságcserével - amely kimondatlanul az esztétikaiturisztikai céloknak is megfelel (vö. Mitchell 1997). Egyes képviselőjelöltek választási ígéretében is megjelent a hajléktalanok „eltűntetése”. A döntéshozók általában találtak „best practice”-t a szegénység, hajléktalanság láthatatlanná tételére, nyugati (ezen belül amerikai) mintákat alkalmazva próbálnak megfelelni a polgárok, turisták igényeinek - közegészségügyi, esztétikai, turisztikai célokat hangoztatva (vö. Mitchell 1997; Amman 2000).

A lehívható források felhasználásával a helyi önkormányzatok enyhíteni tudnak a lakással rendelkezök számla-gondjain, azonban forráshiányos a legtöbb gazdálkodás. Azonban azok, akiknek nincs lakásuk, lakáscélú segélyt nem kapnak. Az ő számukra fontosabb, hogy a megélhetést a jóléti kiadások csökkenése mellett milyen forrásokból tudják pótolni. Így a hajléktalanok ellátásában jelentős szerep jut az állami szervek mellett a civileknek is. A civilek egy része egyházi kötődésű (baptisták, ferencesek stb.), mások emberjogi irányból közelítik meg a hajléktalan kérdést. Amellett, hogy ezen szervezetek kiemelkedő munkát végeznek a problémák enyhítésében, meg kell említeni, hogy szintén forráshiánnyal küzdenek, amely részben a posztszocialista civil szféra sajátsága is, nevezetesen, hogy a civil szféra hosszú szünet után éledt újjá a kilencvenes években, s minthogy sokan egyfajta pénzkereseti módnak tekintik az adománygyüjtést, mindennemủ segítés nélkül, a segítőszervezetek iránti bizalom labilis. A problémák és a segítő szervezetek bemutatását szolgálja a Szolidaritás Éjszakája, amikor az éjszakát forró tea és takaró kíséretében sokan az utcán töltik, hogy empátiájukat fejezzék ki a hajléktalanok iránt. A civil szervezetek nagy szerepet játszanak az ételosztásban, meleg takarók kiosztásában, a 
diszpécser-szolgálat segítségével a segítségre szorulók elérésben. A szociális védőháló lyukait a civil kezdeményezések próbálják foldozni, azonban azt, hogy a jóléti kiadások csökkenésével vagy a problémák elhúzódásával ne váljanak további személyek hajléktalanná, nemigen tudják megakadályozni. A növekvő létszámleépítések, az alkalmi munkások kiszolgáltatottsága, a kilakoltatások lassan növekedö mértéke nem segíti megakadályozni a folyamatot. A döntéshozók az egyén felelösségére helyezik a hangsúlyt: a munkanélküliek - ha más státuszban is - munkához juthatnak, a segélyezettek java részét megpróbálják munkába állítani, $s$ ha nem fogadják el, akkor a segély megszünhet. A preventív tevékenységek forráshiányosak, az átképzések rosszul orientáltak, a nyugdíjak reálértéke jó esetben is stagnál, a bölcsödék túltelítettek, így az anyukák nem tudnak visszatérni a munkába.

A neoliberális állam fokozatosan kivonul a szolidaritást szolgáló intézmények müködtetéséből, a leginkább rászorulók magukra maradnak, miközben a civil szféra forráshiányos - mindez kitágítja és újratermeli a szegénységet, s ezen belül a hajléktalanságot.

\section{Posztszocialista szegénység Magyarországon}

A posztszocialista szegénység tehát két csoportból tevődik össze. Egy része a szocializmusban is szegény, deprivált volt, akik elsősorban életmódjuknak köszönhetỏen a szocializmusban sem és később sem voltak képesek a maguk számára jobb életlehetőséget biztosítani. Öket már a kilencvenes évek elejétől jelentős mértékben érintette a munkanélküliség és a lecsúszás. Másik csoportja a szegénységnek egy viszonylag jó, alsó középosztályi pozícióból hullott lefelé - a munkanélküliség által vagy a piacgazdaság elsőként elbukott vállalkozóiként, esetleg nyugdíjasként (ld. Spéder 2002). Ez a csoport a helyzetüket még súlyosabban értékelte, hiszen a depriváció elöször érintette meg öket. A csalódottság és kirekesztettség sokszor konfliktusokhoz vezetett a családon és a szük környezeten belül. A „túlélés" esélyét a takarékoskodásban vagy a szebb jövő reményében a kölcsönök felvételében látták. Továbbá meg kell említeni a kisnyugdijasokat, valamint a gyermekeket érintő szegénységet (Spéder 2000; 2002).

Bárhonnan is érkeztek, a takarékosság és a napról napra való élés, az élelmiszerés gyógyszerhiányos életmód, az alkalmi munka, a feketemunka többségüket érinti (Simonyi 1995; Laki 2003). A középosztályi helyzetböl érkezettek frissen tapasztalhatták a családi kooperációk széthullását, a munkásszállón lakók többsége ezt már megszokta.

A munkanélküliség hirtelen megjelenése volt az, amely a legtöbbjüket mind anyagilag, mind pszichésen súlyosan érintette. 1992-95 között tetőződött a tömeges leépítés (Laki 2003), ekkorra a munkanélküliség fogalma beivódott a köztudatba. A munkanélküliség olyannyira sokakat érint, hogy a kölcsönös segítségnyújtás szinte lehetetlenné válik, nem tudnak félretenni és felhalmozni, ha baj van, akkor nincs kihez és mihez fordulniuk (Laki 2003). 
Nagy Terézia: Átmenet a szocializmus rejtett hajléktalan világából a kvázi jóléti szociális védőhálóba. - Tér és Társadalom, 23. 2009. 3. 79-96. p.

TÉT XXIII. évf. 2009 - 3

Átmenet a szocializmus...

87

Akinek van munkája, az önkizsákmányoló módon dolgozik, mégha az svarc vagy alkalmi munka is, akiknek nincs, azokat a semmittevés kultúrája érinti meg. Akinek lakáshitele volt, lehet, hogy nehezen tudta fizetni, esetleg a rezsivel volt gondja, a tartozások az alsóbb társadalmi csoportokban sokaktól elvitték a lakást. Némelyek kevésbé komfortos lakást vagy tanyát tudtak helyette vásárolni, esetleg albérletbe kényszerültek.

\section{Új jelenség: a hajléktalanság}

A hajléktalanság ismeretlen volt a szocializmusban: aki beilleszkedett a társadalomba, annak volt munkája (Ferge 1982), akinek munkája volt, annak volt hol laknia. Aki mégis az utcán élt, az önszántából választotta ezt a sorsot - őket azonban a társadalom megvetette. A renđszerváltás után bekövetkezö makrogazdasági és makrotársadalmi folyamatok következtében azonban sokan kerültek utcára, anélkül, hogy maguk választották volna ezt az utat ${ }^{3}$. Elsősorban azok, akik a munkájukkal együtt a helyüket is elveszítették a munkásszállókon, s azok, akik a munkásszállók bezárásával nem tudtak hova hazamenni. Majd sorban azok, akik valamilyen oknál fogva nem tudtak alkalmazkodni az új körülményekhez: képesítésük, képességük hiányában, alkalmazkodási képtelenség folyományaként. 1992 telén már látható volt az, hogy tömegeket érint a hajléktalanság (Iványi 1997). Ekkor indultak meg az első civil kezdeményezések is, indultak az első hajléktalanszállók, átmeneti és nappali otthonok, ételosztások. A hajléktalanoknak azzal kellett szembenézniük, amely teljesen valószerútlen volt a szocializmusban: a hajléktalansággal, nyomorral, a kiszolgáltatottsággal. A társadalom számára pedig mindez nyilvánvalóvá tette, hogy az állam, a társadalom nem menti meg ettől a sorstól a tagjait.

\section{A szegénység és hajléktalanság a számok tükrében}

A szocializmus utolsó évtizedében, reprezentatív felmérések szerint a lakosság 11\%-a deprivált, s 20\%-a veszélyeztetett volt (Bokor 1987). Bokor maga is kiemeli, hogy a ,szegénység" nehezen vizsgálható, mert amellett, hogy politikai tabu, hiányzik a szegénység-tudat is. Így a szegénység attribútumain keresztül a depriváltságot vizsgálták. A renđszerváltás után a szegénység szociológiai vizsgálata során már egy másik szegénység-koncepcióval dolgoztak (Spéder 2002), s megpróbálták a szegénységet objektív mérőszámok közé szoritani. 1997-re a szegénység 13\%-nyira nött ${ }^{4}$, de a rendszeres pénzzavar mintegy 30\%-át érintette a magyaroknak (Spéder 2002, 57). Ekkorra a szegénység-tuđat kialakult és felszabađult, így lehetôvé vált a szegénység szubjektív (önértékeléssel egybekötött) mérése - a magyar társadalom mintegy negyede érzezte szegénynek önmagát. Életmódjukról azonban csak kevés képet kapunk.

A különböző kutatások különbözö szegénység-definíciókat alkalmaztak, s így nem lehetünk biztosak abban, hogy a $13 \%$ vagy a megközelítỏleg $25 \%$ a pontosabb. Az átlagos jövedelemtöl való eltérésre van ađatunk, a szegényeket, a margón élöket azonban ez még nem mutatja meg. 
Nagy Terézia: Átmenet a szocializmus rejtett hajléktalan világából a kvázi jóléti szociális védőhálóba. - Tér és Társadalom, 23. 2009. 3. 79-96. p.

A hajléktalanok számáról még kevésbé tudunk nyilatkozni. 2005 februárjában kezdeményezték először a hajléktalanok összeírását, melynek eredményeként mintegy 10 ezer hajléktalant vettek nyilvántartásba országosan. Az összeirás, ha jó kezdeményezés is volt, kudarcba fulladt az eltérő hajléktalan-definíciók, a hajléktalanok identifikációja, válaszadási készsége miatt. Szegeden 13 hajléktalant számláltak meg, mivel ott úgy definiálták, hogy azokat kell számba venni, akik az utcán életmódszerüen élnek, mindenféle intézményi támogatás nélkül. Így kimaradt az a mintegy 560 hajléktalan, akik az intézményekkel kapcsolatban állnak, s még továbbiak, akik ugyan valójában az utcán élnek, a definíció-értelmezésnek megfelelnek, de az összeírásban nem vettek részt. Kb. 800-1200 hajléktalan él Szegeden és a környezö erdökben, vélik a szakemberek (J. K., a hajléktalanszálló vezetöjének szóbeli közlése) - ez a város lakosságának 0,5-0,7\%-a. Hogy más városokban és a fövárosban mennyi lehet az eltérés a valós létszám és a megszámoltak létszáma között, sejteni sem lehet. A hajléktalanszállók télen teljes kihasználtsággal működnek, így ekkor ideiglenes férőhelyeket is a rendelkezésükre bocsátanak. Az országos mutatók szerint a szállások, népkonyhák kihasználtsága éves szinten nem érte el a teljes kapacitást, a nappali melegedők forgalma viszont felülmúlta a kapacitásokat (Kapros 2008).

\section{Az ủj kihívásoktól a hajléktalanságig vezetô utakig}

A hajléktalan-élettörténetek interpretálásakor jól strukturált, megkonstruált történetekkel találkoztunk elöször, melyek a késöbbi interjúk során egészültek ki mélyebb elbeszélésekkel. A fogyasztásra felkínált történetekben több, visszatérö motívum volt megfigyelhetö, melyek tükrözték a körülvevő társadalom morálját, indirekt módon a szenzációéhségét is, de ugyanakkor jól bemutatták a hajléktalanságig vezetô út motívumait is.

Referáltak a posztszocialista társadalom és gazdaság változásaira és az új kihívásokra éppúgy, mint az egyéni életutakat övező konfliktusokra és konfliktus-kezelö mechanizmusokra. Láttatták azt, ahogy a bizonytalanság úrrá lett az ipari és mezőgazdasági munkások rétegein, ahogy a változásokhoz való alkalmazkodás kudarcba fulladt a részükroöl. S az értetlenséget, mellyel néha szinte kívülröl figyelték az életüket, melyben föszereplők is lehettek volna.

\section{Strukturális és individuális okok}

A hajléktalansághoz vezető okok egy része strukturális, mások individuális tényezőkre vezethetök vissza, sok esetben azonban e kettő valamilyen keverékének eredményeképp kerül az egyén az utcára (Burt et al. 2001).

A strukturális okok egy része a rendszerváltást követő gazdasági struktúra átalakításának következménye, míg mások a társadalompolitika változására vezethetök vissza. Emellett a rendszerváltást megelőző időszak egyes sajátságainak következményei is ide sorolhatók. A tartós munkanélküliség, az illegális (fekete) munka - a 
Nagy Terézia: Átmenet a szocializmus rejtett hajléktalan világából a kvázi jóléti szociális védőhálóba. - Tér és Társadalom, 23. 2009. 3. 79-96. p.

TÉT XXIII. évf. 2009 - 3

Átmenet a szocializmus...

bizonytalan jövedelemforrás -, a munkásszállók bezárása, a szakképzetlen (és immár felesleges) munkaerő, a romló lakáskörülmények jelentős részben strukturális okai a hajléktalanságnak. Az állami gondozásból, börtönből kikerülő egyének rehabilitációjának hiánya, a rendszerváltás előtti továbbképzések hiánya további gondot okoz. A kistőkéjủ vagy kényszervállalkozók a keményedő gazdasági feltételek mellett sokszor nem tudtak lépést tartani. Mindez jól mutatja, hogy az új piacgazdasági kihívások a társadalom egyes rétegeit váratlanul érik, és abban ellehetetlenülnek.

$\mathrm{Az}$ individuális tényezők között a pszichiátriai betegségek ${ }^{5}$ és az alkoholizmus ${ }^{6}$ vannak vezető helyen, de a börtön, a rossz családi körülmények, a válások, a rossz döntések is megjelennek az interjúkban. Ezt nehezíti, hogy a pszichiátriai kezelés szégyenletes, az idősotthonok és pszichiátriai intézmények túltelítettek.

További problémát jelent, hogy a kisnyugdíjasok egy része nem tudja a számláit fizetni, esetleg eltartók, rokonok kényszerítik, hogy a lakását eladja - egy részǘk a hajléktalanok számát növeli később.

\section{A hajléktalan lét a férfiak világa és kiké még?}

A vizsgált területen a hajléktalanok jelentős többsége férfi és csak elvétve akad nő vagy gyermek. Ennek okait a kutatók és a hajléktalanok különbözőképpen hangsúlyozzák. A hajléktalanok szempontjából a válás után az utcára került férfiak szentimentális történetét ismerhetjük meg, amelyben a nő a jussot elbitorlóként nyilvánvalóan nem kerül utcára. Az esetlegesen mégis utcára került nők a szempontjukból úgy tủnik, hasonló stációkat járnak be. A kutatók szemében ezen ok mellett számos más ok is megjelenik. Így az alkoholfogyasztás, a drogfogyasztás, valamint a tartós munkanélküliség és iskolázatlanság is olyan tényezők, amelyek a nők hajléktalanná válásában szerepet játszhatnak, éppúgy, mint a férfiakéban.

Szemben az amerikai hajléktalansággal, a magyar hajléktalanok többsége magyar/fehér. Csak nagyon kevés közülük az, aki cigány kötődését jelezte, s a kutatók álláspontja is hasonló. Hogy miért nincs több cigány a hajléktalanok között, arra a kapcsolatháló elemzés segítségével válaszolhatunk. A cigányok körében a számos gyenge és sok erős kötésnek köszönhetően, a családi-közösségi védőháló nem teszi (könnyen) lehetővé a kiszakadást, és így a keresetszerzési mód vagy fedél nélkül való létet sem. A kötések száma jelentősebb, mint a magyarok körében, még akkor is, ha az adott cigány származású egyén nevelôintézetben nő fel, vagy más módon elszakadt/eltávolodott a családtól. Más, volt ipari városokban kissé magasabb a számuk, de még ott is túlnyomórészt magyarok a hajléktalanok.

Koldusok esetében - amely nem feltétlenül azonos a hajléktalansággal - a cigány származásúak nagyobb számban vannak jelen, mint más illegális és szürke (féllegális) jövedelemszerző tevékenységet folytató hajléktalanok körében. Ennek az is oka, hogy a szomszédos Romániából cigány származású koldusokat importáltak "vállalkozók", akik a koldusok jövedelmét elvéve és azokat kiszolgáltatott módon, félig-meddig rabszolgaként alkalmazzák. 
A guberálók egy része, akik a mindennapi szükségleteiket elégítik ki, etnikailag kiegyenlítettek, mégha a társadalom ${ }^{7}$ cigánynak is tekinti mindnyájukat. Azok azonban, akik egyfajta módon szintén guberálók, de a hulladék és lom specifikus tárgyaira irányul az érdeklödésük, nem tartoznak vizsgálatunk tárgyába, de megemlítjük, hogy körükben valóban felülreprezentált a cigányok száma.

Mostanában - ahogy a Magyarországot érintő migrációs áramlás erősödik - a migránsok kis része, néhányuk afrikai, kénytelen átmenetileg hajléktalanszállón meghúzódni, amíg a menekülttáborból az önálló élet felé mozdulnak.

Amellett, hogy a férfiak vannak többségben, a hajléktalanok világa a férfiaké. A férfiak osztják fel egymás között a város különböző területeit, a nők csak e területeken belül élnek vagy „dolgoznak”, de beleszólásuk nincs. A férfiak határozzák meg a hierarchiát - melynek az alján ott vannak maguk a nők is -, ha kell ököllel, ha kell pszichés agresszióval. A hierarchiában nem játszanak szerepet a gyerekek, akik közül számosan már az utcai élet szülöttei, s mind a nök, mind a gyerekek a védelemre csak a közvetlen hozzátartozóktól vagy a munkaadótól számíthatnak -, s ebbe bele kell érteni az adott terület „birtokosát” is.

Így azt mondhatjuk, hogy a hajléktalanok világa jobban férfiközpontú, mint a körülvevő társadalomé, mely világban a nő a hátországot, a békítỏ felet vagy épp a küzdelem tárgyát jelentheti, de valójában testi sajátságainál fogva nem egyenlö partner.

A hajléktalancsoportok a strukturális paraméterek (Angelusz 2000) alapján is körvonalazhatók. A nem-hajléktalanok birtokosok, a hajléktalanok nem birtokosok kitétel további jellemzökkel színesíthető: a jövedelem, iskolázottság, hatalom és érdekérvényesítési képesség mellett az életkort is figyelembe vehetjük. Ezek figyelembevételével azt is láthatjuk, hogy a hajléktalanok társadalmán belül is vannak presztízst képzö paraméterek - az iskolázottság másodlagos, leginkább a keresetszerzés módja a fontos, illetve a szállástípus. Az időszakokon belül rendszeres munkát végző, a napibéres, az illegális jövedelemszerző (kivéve a koldus), a hulladékhasznosítók közül a piacozók, a koldus, a lejmoló, a hulladékhasznosítók közül azok, akik saját célra használják elsősorban a fellelt dolgokat - ezek a grádicsai a keresetszerzés típusainak (vö. Utasi 1987). Ezen kívül, a hierarchiában egyénileg más-más helyre értékelt keresetszerzési mód: a verekedéssel, testi erövel jövedelemre szert tevők, a prostituáltak, a társak által fenntartott, s a másokat meglopó személyek módjai. A hajléktalanszállót igénybe vevők „lecsúszottnak” tekintettek, szemben azokkal, akik függetlenül tudnak élni, de akik erdőlakó-függetlenek, a hierarchiában lentebb helyezkednek el, mint a városlakó-függetlenek. A hajléktalanként eltöltött telek száma is szerepet játszik a presztízs-megítélésben, éppúgy, mint az, ha valaki rendszeres jövedelemmel (nyugdij, rokkantnyugdij, segély) rendelkezik - ezek a túlélési képesség mérésére is szolgálnak maguk között ${ }^{8}$.

Demográfiai szempontból a szegedi hajléktalanoknak is (vö. von Mahs 2005, 933) jelentös hányada több mint három telet töltött az utcán, többségükben közép- és időskorúak, s korukból adódóan is nagy részük családos vagy elvált; agglegény, vénleány nem volt közöttük. 
Nagy Terézia: Átmenet a szocializmus rejtett hajléktalan világából a kvázi jóléti szociális védőhálóba. - Tér és Társadalom, 23. 2009. 3. 79-96. p.

TÉT XXIII. évf. 2009 — 3

Átmenet a szocializmus...

\section{Kapcsolatok, kizárás, bezárás - hogyan lehet hajléktalannak maradni}

A kapcsolatháló elemzésekor azt tapasztaltuk, hogy az ún. erős kötések, mint a vérszerinti és választott családi kapcsolatok a hajléktalanok körében jórészt felbomlottak vagy konfliktusosak. A gyenge kötések, amelyek a baráti, munkahelyi, informális és formális kapcsolatokat foglalják magukban, a jelenre orientálódnak, a régi kapcsolatok nagyrészt felbomlottak, s a meglévők elsősorban a hajléktalan társakra irányulnak ${ }^{9}$. A hajléktalanok világán túlra mutató kapcsolatok olyan egyénekre irányulnak, akik maguk nem képesek segíteni a hajléktalant. A hajléktalanokat segítő állami és civil szervezetek ugyan megjelennek a kapcsolathálókban, de csak azok perifériáján, $\mathrm{s}$ a segitő tevékenységek inkább a fenntartásra irányulnak, mintsem a társadalomba való visszavezetésre (a kevés rehabilitációt segítỏ tevékenység viszont sokszor kudarcba fullad a következőkben vázolt kapcsolati sajátságoknál fogva).

A hajléktalanok gyakran számolnak be arról, hogy a hajléktalan sorból való kilépést nagyban hátráltatja a többi hajléktalan, akik a kapcsolatot kihasználva mintegy visszahúzó erôt jelentenek. Ráadásul a patrónus-kliensi kapcsolatok egy részében a patrónus a hajléktalan (aki másik hajléktalant vagy a nem-hajléktalan gyermekeit támogatja).

A szükség kikényszeríti a hajléktalanok közötti kapcsolatokban a kölcsönösséget, a kölcsönösség segíti a szükségletek kielégítését, de ez egy állandó jelenlétet is jelent a másik életében. Megosztják mindazt, amijük van, az élelmet, alkoholt és a dohányt, a szállást, és védik is egymást. Az életmód és a csoporton belülre mutató kapcsolatok mellett a reményvesztettség, jövőbe vetett hit elvesztése, a fizikai és mentális leépülés azok, amelyek a bezáródást erösítik. És mindezek az idő előrehaladtával nőnek: minél tovább marad valaki az utcán, annál kisebb az esélye a „visszatérésre”. A kölcsönös függés ráadásul a hajléktalan létbe való bezáródáshoz is vezet, amelyet persze nem értelmezhetünk a kizártság nélkül (mindehhez ld. Nagy 2004).

A hajléktalanság a fizikai szükségleteken túl a társadalom normális mủködésének folyamatából is kizárja az egyént. A társadalmi és kulturális rendszerekből is kizártnak kell tekintenünk öket, minthogy a társadalom többsége szimbolikusan is és ténylegesen is elfordul tỏlük (Id. az egyenlöség és egyenlötlenség kapcsán: Frankfurt 1997; Caldeira 1999, 102-105; a társadalmi kizárásról: Jordan 1996). Az utcai élet, a sajátos életmód és az alkoholproblémák a társadalom rosszallását váltják ki, de még a szociális intézmények is negatív megitélés alá esnek.

Az épületek, az otthonok - a világ közepe, amely a biztonságot, a jelentőségteljesség érzetét keltik, egy rendezett világot jelenítenek meg. E nélkül a bizonytalanság, a jelentéktelenség, a védtelenség, a megfosztottság válhatnak kulcsszavainkká. A hajléktalanok az otthon biztonságától vannak megfosztva, s egyúttal attól, hogy a testi szükségleteiket intim környezetben elégíthessék ki.

A kizártság egy másik vetülete a jogfosztottság. A hajléktalanok ugyan elvi szinten rendelkeznek szavazati joggal, de azzal élni nem tudnak, mert egy részük nem rendelkezik bejelentett lakcímmel, míg mások a személyi igazolványukat pénzért 
eladták. Így az alapvetö jogokhoz való hozzáférésük is korlátozódik (vö. Lynch 2002). Néhányan arról is beszámoltak, hogy a szociális segélyeket sem tudják igénybe venni, mert nem tudják maguk elintézni. Ugyanígy, ha nem a hajléktalanok számára külön rendelt orvoshoz fordul (nincs közgyógy-ellátottságáról papírja), s nem nyugdíjas, újabban nem jogosult az ingyenes ellátásra.

\section{A közterek használata, a használat kriminalizációja}

A tér kisajátítását elöször a hajléktalanok végezték, s csak az utóbbi években beszélhetünk arról a folyamatról, amikor azt a helyi szervek, a polgárok visszaprivatizálják, szempontunkból inkább: kommunizálják. A magyar hajléktalanok a kilencvenes évektól kezdődően el-elprivatizáltak egy-egy közteret az által, hogy a városlakók számára a hajléktalan által elfoglalt térrész eltávolodik a saját térrészétől, a neutrális köztér egy része elutasításra lel a számukra. A tér mindenkié, azonban akkor, amikor valaki ott él, a városlakók szeme elfordul, mintha ezzel is a saját és a másik ember intimitását védené. Ez az intimitás megadása biztosítja a legitimitását az ott élőknek. Még akkor is, amikor abból élnek, hogy mások észreveszik őket - mint pl. a koldusok. A hajléktalanok szempontjából ez sokkal egyértelműbb megközelítést ad. „Ez a tér a miénk, én és a tesóm [vértestvér] szoktunk itt lenni. Ha jön egy másik csöves, elhajtjuk, mert ez a miénk. Ide járnak vissza azok, akik hoznak nekünk valamit, itt találnak meg minket. Tavaly óta ez a miénk. Azelött nem volt senkié, egy koldus volt itt, annyi. A sétálóutca a Csibakéké, meg ott van a Tibor. Néha átmegyünk hozzájuk, de ott soha nem dolgozunk [koldulunk]." (O. F. 43 éves hajléktalan férfi).

Védett területek tartoznak egy-egy régi hajléktalanhoz. A város közterei és utcái felosztottak, mert ez biztosítja a megélhetésüket és a biztonságukat. Az új foglalás véres viták eredménye lehet csak. A terek, az épületek kis beugrói, liftházak, a köztéri padok egy része, a temetö kriptái, az ártéri erdö, $s$ még sok más hely is végigjárta az utat a neutralizált tér privatizációjától az „elkommunalizálásig”. A város újfajta övezetei (ld. Caldeira 1999) jelennek meg: vannak olyan területek, ahol a hajléktalanok otthonra lelnek, s olyanok, ahol nem. Olyanok, amelyeken alszanak, s olyanok, amelyeken csak „dolgoznak”. Ez utóbbi lehet a város legforgalmasabb területe, ahol koldulni, lejmolni próbálnak, vagy éppen, ahol guberálhatnak. (A tér „belakásáról és az „idegenekröl” ld. Bridge 2001; a tér használatáról ld. Sassen 1999; a guberálásról ld. Mitchell-Heynen 2007).

Szeged volt az első magyar város, amely megalkotta az ún. koldustörvényt, melynek értelmében tilos a koldulás - pénzbüntetéssel büntetendő. A különböző koldustörvények a hely privatizációit megnehezítették: az ablakmosás, koldulás tilos (így a munka területe tünik el), a padokra sok helyen karfát szereltek ${ }^{10}$, a lépcsőházakat és az építési területeket az elmúlt 15 évben inkább zárják " (így az alvás területe szükül). A lakásfoglalás Magyarországon ritka esemény, $\mathrm{s}$ akkor is csak időlegesen tartható fenn. Civil szervezetek aggályaikat fejezték ki a koldustörvények alkotmányosságára vonatkozóan, vélik: a rendeletek az egyén általános cselekvési szabad- 
Nagy Terézia: Átmenet a szocializmus rejtett hajléktalan világából a kvázi jóléti szociális védőhálóba. - Tér és Társadalom, 23. 2009. 3. 79-96. p.

ságát, valamint emberi méltósághoz és szabad mozgáshoz való jogát csorbítja (vö. Mitchell 1997 - a jogok és a szabadságjogok megcsorbítása kapesán).

A belvárostól távol nyitották az állandó és az ideiglenes hajléktalanszállókat, a város másik végén a nappali melegedöt, de a közöttük vezetö útvonal a belvároson keresztül is vezethet, $\mathrm{s}$ nem ritkán a civilek az ételosztásokat a belváros frekventált terein ejtik meg, így a hajléktalanok nincsenek tökéletesen kizárva a belvárosból. A szállók további kizárást is jelentenek: a hajléktalanok egyes csoportjai elutasítják azokat, akik igénybe veszik, másrészt véglegesnek tekintik a hajléktalan-állapotot azok, akik igénybe veszik, a függetlenség végső feladását jelenti.

Amellett, hogy a frekventált helyekröl némileg a különböző tiltások miatt (általában átmenetileg) sikerül eltávolítani a hajléktalanokat, láthatjuk, hogy majdnem minden, ami a hajléktalanok sajátos életformájával együtt jár: tilos. A vagyonban kárt tenni, lopni egyértelmủen tilos, tilos továbbá a koldulás, a közterület életformaszerü használata. A visszaélésszerủ gyógyszerhasználat, szipuzás és utcai alkoholfogyasztás és ürítés viszonylag kevesebbszer kerül büntetésre - ezen kihágásokra nem figyelnek annyira oda, de tilos (ld. még Mitchell 1997; Amman 2000; Lynch 2002). Az üzletek biztonsági örei is elküldik a hajléktalanokat, ha úgy érzik, hogy zavarják az üzlet forgalmát. Szegeden az ablakmosás a forgalmi lámpáknál sosem volt általános, jelenleg a bevásárlókocsi visszatolása egy pénzkereseti mód, amelyet még nem tiltanak hivatalosan.

\section{Összegzés}

A magyar hajléktalanság a sajátos történelmi-politikai-gazdasági környezet változásaival párhuzamosan alakul, s a különbözỏ irányú szociálpolitikai törekvések, a forráshiányos gazdálkodás, a kormányzat és önkormányzatok „best practice”követő magatartása adja a különbségeket és az azonosságokat az amerikai hajléktalan világ és policyhoz képest. Jelen tanulmányban igyekeztünk a magyar és speciálisan szegedi jelenségeket összegezve választ találni arra a kérdésre, hogy melyek azok a vonások, amelyeket a világ bármely hajléktalan csoportját vizsgálva megtalálunk - igy a strukturális és individuális okok jelentős része -, s melyek azok, amelyek a neoliberális best practice-k átvételével kerültek a magyar „tünetek” közé, úgyismint a hajléktalanok belvárosi ellehetetlenítése és kiszorítása, a segélyezés és a felelösség összekapcsolása. Feltehetö, hogy a természetes válaszreakciók, melyek a hajléktalanságot, mint társadalmi problémát övezik, „szerencsésen” találkoznak a magyar policy követô magatartásával. 


\section{Jegyzetek}

'Értsd itt: erdőben, ártéri erdőben, liftházban, épületek beugróiban, lépcsőházban.

${ }^{2}$ A népességnövekedés és ezen keresztül az infrastrukturális fejlesztések és általában a szintentartás végett egy falu, Tarnabod került a szociális tárca, a Magyar Máltai Szeretetszolgálat, a Hajléktalanokért Közalapítvány és a helyi önkormányzat 'Befogadó Falu' programjába. Hajléktalancsaládokat fogadtak be, akik lakást és az életkezdéshez szükséges anyagi javakat, valamint munkát kaptak. A családok egy része sikeresen adaptálódott a vidéki élethez.

${ }^{3}$ Természetesen vannak olyanok, akik önként költöznek ki, valamilyen (ideológiai) megfontolásból vagy jobb lehetöségnek tekintik az utcát, mint a helyet, ahol éltek (vö. May 2000).

${ }^{4}$ Ez körülbelül megfelel az USA mutatójának (13,7\%), ahogy Burt és szerzőtársai (2001) jelezték.

${ }^{5}$ Sullivan és szerzőtársai (2000) megállapítják, hogy a mentális betegségekkel rendelkező hajléktalanok komoly szociális és egészségi problémákkal rendelkeznek. A szegedi hajléktalanok jelentös hányadát szintén érinti a skizofrénia, depresszió, bipolaritás vagy más pszichiátriai betegségek, ők veszélyeztetettebbek más hajléktalanoknál a diszintegrációra, a társas kapcsolatok elvesztésére.

${ }^{6}$ Megjegyzendö, hogy a lakosság 10\%-a problémás alkoholfogyasztó (Elekes 2000).

${ }^{7}$ Azt, hogy ki a cigány, az önbevallás mellett a magyar kutatók gyakran olyan módszereket alkalmazva határozzák meg, hogy figyelembe veszik a szükebb társas környezet ítéletét is. Ennek segítségével próbálják meghatározni a cigányság valódi létszámát, ami önbevallás alapján jelentősen kisebb volna.

${ }^{8}$ Láthatjuk, hogy az in-group megközelités a szociális szolgáltatásokra épülö stratégia (Snow-Anderson - idézi von Mahs 2005, 950) ellenében hat, bár a kapcsolatháló és némiképp a munka-orientáció pozitívabb megítélés alá esik.

${ }^{9}$ Ezért nem elégséges a kapcsolódó és izolált elkülönítés (vö. Burt et al. 2001), a kapcsolatok minősége és iránya is legalább ennyire fontos a szempontunkból. Emellett a kapcsolatok száma a hajléktalan populációban nagyobb, mint azon kívül, így ez sem lenne elégséges mutató.

${ }^{10}$ Egyes illegális civil kezdeményezések megpróbálnak szembemenni ezekkel, s leszerelik a padok karfäit, amelyek megosztják a felületet, hogy ne lehessen rajta aludni, az ülörészeket határoló szegecseket kiszedik.

${ }^{11}$ Hivatalosan az építőanyagok lopása, lelakás és értékcsökkenés miatt.

\section{Irodalom}

Angelusz R. (2000) A láthatóság görbe tükrei. Új Mandátum, Budapest.

Amman, J.J. (2000) Addressing quality of life crimes in our cities: criminalization, community courts and community compassion. - Saint Louis University Law Journal. 44. 811-820. o.

Bokor Á. (1987) Szegénység a mai Magyarországon. Magvető Kiadó, Budapest.

Borboly I.-Horváth G.-Kovách I.-Nagy R. (2003) A feketegazdaság: érdekek és szereplök. - Kovách I. (szerk.) Hatalom és társadalmi változás. A posztszocializmus vége. Szociológiai tanulmányok. Napvilág Kiadó, Budapest. 183-215. o.

Bridge, G.-Watson, S. (2001) Retext(ur)ing the city. - City. 3. 350-362. o.

Burt, M.-Aron, L.Y.-Lee, E.-Valente, J. (2001) Helping America's homeless: Emergency shelter or affordable housing? The Urban Institute Press, Washington. http://www.urban.org/pubs/ homeless/chapterl.html

Caldeira, T. (1999) Fortified Enclaves: The New Urban Segregation. - Low, S. (ed.) Theorizing the City: The New Urban Anthropology Reader. Rutgers University Press, New Brunswick. 83-108. o.

Costa Nunez, R. (1996) The New Poverty. Homeless Families in America. Plenum Press, New YorkLondon.

Diósi Á. (1978) Szövőlányok. - Kulturra és Közösség. 4. 56-74. o.

Eberstadt, N. (1988) The Poverty of Communism. Transaction Books, New Brunswick-Oxford.

Elekes Zs. (2000) Alkoholprobléma az ezredvégi Magyarországon. - Elekes Zs.-Spéder Zs. (szerk.) Törések és kötések a magyar társadalomban. Andorka Rudolf Társadalomtudományi Társaság - Századvég Kiadó, Budapest. 152-169. o.

Ferge Zs. (1982) Társadalmi újratermelés és társadalompolitika. Közgazdasági és Jogi Kiadó, Budapest. 
Frankfurt, H. (1997) Equality and Respect, - Social Research. 1. 3-15. o.

Gönczöl K. (1982) A hátrányos helyzet és a bünözés. - Valóság. 8. 61-72. o.

Gönczöl K. (1991) Bünös szegények. Közgazdasági és Jogi Kiadó, Budapest.

Hazra, A. (2005) Poverty and Politics: Some Empirical Observations. Paper presented at the conference Livelihoods and Poverty Reduction: Lessons From Eastern India, 25-27 September 2001. www.anthrobase.com/txt/H/Hazra_A 01.htm.

Höjdestrand, T. (2003) The Soviet-Russian Production of Homelessness: Propiska, Housing, Privatisation. www.anthrobase.com/txt/H/Hoejdestrand_T_01.htm Letöltve: 2005. 02. 19.

Iványi G. (1997) Hajléktalanok. Sík Kiadó, Budapest.

Jancius A. (2002) Social Markets and the Meaning of Work in Eastern Germany, - Kockel, U. (ed.) Culture and Economy: Contemporary Perspectives. Ashgate, Hampshire. 60-70. o.

Jordan B. (1996) A Theory of Poverty and Social Exclusion. Polity Press, Cornwall.

Kapros T. (2008) Szociális védóháló a régiókban. Központi Statisztikai Hivatal, Miskolc.

Kemény, I. (1979) Poverty in Hungary. - Social Science Information. 2. 247-267. o.

Köbányai J. (1980) A „csöves kérdés”, - Kultúra és Közösség. 4. 95-101 . o.

Köbányai J. (1982) A margón. - Valóság. 1. 93--101. o.

Kürti, L. (2002) Youth and State in Hungary. Capitalism, Communism and Class. Pluto Press, London.

Laki L. (2003) A szegénység közelebbről. - Kovách I. (szerk.) Hatalom és társadalmi változás. A posztszocializmus vége. Szociológiai tanulmányok. Napvilág Kiadó, Budapest. 113-131. o.

Láng K.-Nyilas G. (1987) Ideiglenes állandóság. Tanulmány a munkásszálláson élők életkörülményeiről és rétegződéséröl. - Utasi Á. (szerk.) Peremhelyzetek. Mühelytanulmányok. Rétegzödés-modell vizsgálat VIII. Társadalomtudományi Intézet, Budapest. 33-100. o.

Lynch, Ph. (2002) Begging for Change. Homelessness and the Law. - Melbourne University Law Review. http:/www.austlii.edu.au/au/journals/MULR/2002/35.html

Mahs, J. von (2005) The Sociopatial Exclusion of Single Homeless People in Berlin and Los Angeles. American Behavioral Scientist. 8. 928-960. o.

Mátyus A. (1978) Lakóhely és életmód. - Kultúra és Közösség. 4. 49-55. o.

May, J. (2000) Of nomads and vagrants: single homlessness and narratives of home as place. Enviroment and Planning D: Society and Space. 18. 737-759. o.

Mitchell, D. (1997) The annihilation of space by law: the roots and implications of anti-homeless laws in the United States. - Antipode. 3.303-335. o.

Mitchell, D.-Heynen, N. (2007) The Geography of Survival and the Right to the City: Speculations on Surveillance, Legal Innovation, and the Criminalization of Intervention. - Urban Geography, 6. 611-632. o.

Nagy T. (2004) Kapcsolatháló elemzés egy szegedi hajléktalancsoportban. - Pászka I. (szerk.) A látóhatár mögött. Szociológiai tanulmányok. Belvedere Meridionale, Szeged. 91-139. o.

Sassen, S. (1999) Whose City Is It? Globalization and the Formation of New Claims. - Holston, J. (ed.) Cities and Citizenship. Duke University Press, Durham. 177-194. o.

Šiklová, J. (1996) What Did We Lose After 1989? - Social Research. 2. 531-41. o.

Simonyi Á. (1995) Munka nélkül. Családi alkalmazkodási stratégiák és hiányuk. - Szociológiai Szemle. 1. 55-70. o.

Spéder Zs. (2000) Az inaktívak tagolódása az 1990-es évek Magyarországán. - Elekes Zs.--Spéder Zs. (szerk.) Törések és kötések a magyar társadalomban. Andorka Rudolf Társadalomtudományi Társaság - Századvég Kiadó, Budapest. 69--96. o.

Spéder Zs. (2002) A szegénység változó arcai. Tények és értelmezések. Andorka Rudolf Társadalomtudományi Társaság - Századvég Kiadó, Budapest.

Sullivan, G.-Burnam, A.-Koegel, P.-Hollenberg, J. (2000) Quality of life of homeless persons with mental illness: results from the course-of-homelessness study. - Psyhiatric Services. 9. 1135-1141. o.

Szalai, J. (1997) Power and Poverty. - Social Research. 4. 1403-1422. o.

Timár J.-Nagy E. (2007) A középvárosi dzsentrifikáció társadalmi hatásai a posztszocialista Magyarországon. - Enyedi Gy. (szerk.) A történelmi városközpontok átalakulásának társadalmi hatásai. MTA Társadalomkutató központ, Budapest. 293-319. o.

Tóth I.Gy. (1994) A jóléti rendszer az átmenet időszakában. - Közgazdasági Szemle. 3. 313-340. o.

Utasi A. (1987) Hajléktalanok, csavargók. - Utasi Á. (szerk.) Peremhelyzetek. Mühelytanulmányok. Rétegzódés-modell vizsgálat VIII. Társadalomtudományi Intézet, Budapest. 181-213. o.

Veres S. (1979) A munkásszálló - kérdőjelekkel. - Valóság. 4. 66-79. o. 


\title{
TRANSITION FROM THE HIDDEN HOMELESS WORLD OF SOCIALISM TO THE QUASI-WELFARE SOCIAL SAFETY NET
}

\begin{abstract}
TERÉZIA NAGY
In Hungary after the 2nd World War the homelessness has reappeared in the 1990's as kind of social problem and also as phenomenon. The intention of my study is to show how the homelessness became visible to society, what caused that the problem had was noticed so late, and how the homeless people were before part of the society even at a latent way. My fieldwork was carried out after 2002 in Szeged, a city in southern Hungary. During the research I participated in the everyday lives of homeless groups as an observer and I conducted interviews and I exam the social networks, problems and possibilities of homeless.

In my study I show that the Hungarian circumstances, politics and structural changes how far different from Westerns's are which had taken different historical-economic stages, moreover how these influence the fate of who's becoming homeless. Some 18 years passed after the political transformation, however, those years' special opportunities, limits and changes left their marks on the poorness and homeless of the present time.
\end{abstract}

